Prepared in cooperation with the City of Centralia

\title{
Water Budget of the Upper Chehalis River Basin, Southwestern Washington
}

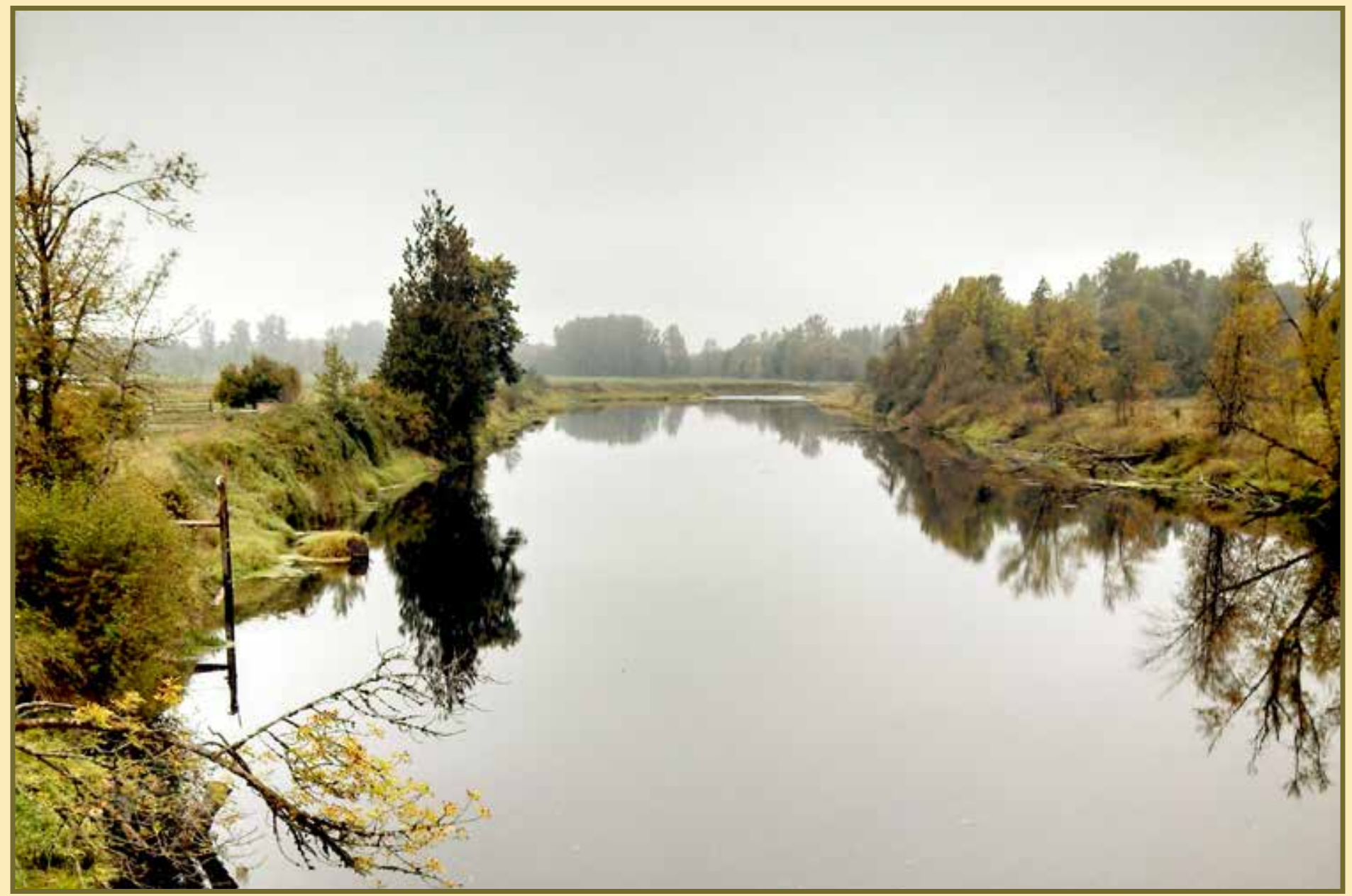

Scientific Investigations Report 2018-5084 
Cover: Photograph showing Chehalis River at Grand Mound, Washington. Photograph by Kevin Linn, U.S. Geological Survey, October 9, 2014. 


\section{Water Budget of the Upper Chehalis River Basin, Southwestern Washington}

By Andrew S. Gendaszek and Wendy B. Welch

Prepared in cooperation with the City of Centrailia

Scientific Investigtions Report 2018-5084 


\title{
U.S. Department of the Interior \\ RYAN K. ZINKE, Secretary
}

\author{
U.S. Geological Survey \\ James F. Reilly II, Director
}

U.S. Geological Survey, Reston, Virginia: 2018

For more information on the USGS — the Federal source for science about the Earth, its natural and living resources, natural hazards, and the environment-visit https://www.usgs.gov or call 1-888-ASK-USGS.

For an overview of USGS information products, including maps, imagery, and publications, visit https://store.usgs.gov.

Any use of trade, firm, or product names is for descriptive purposes only and does not imply endorsement by the U.S. Government.

Although this information product, for the most part, is in the public domain, it also may contain copyrighted materials as noted in the text. Permission to reproduce copyrighted items must be secured from the copyright owner.

Suggested citation:

Gendaszek, A.S., and Welch, W.B., 2018, Water budget of the upper Chehalis River Basin, southwestern Washington: U.S. Geological Survey Scientific Investigations Report 2018-5084, 17 p., https://doi.org/10.3133/sir20185084.

ISSN 2328-0328 (online) 


\section{Contents}

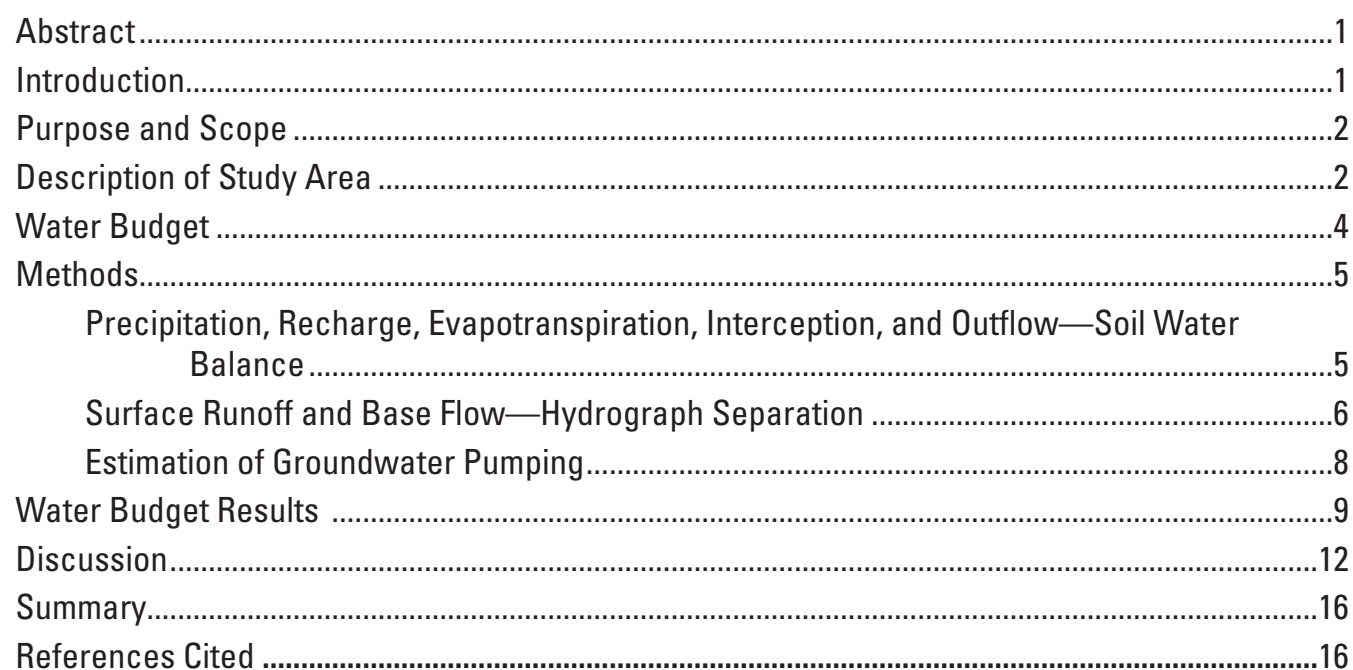

\section{Figures}

1. Map showing location of upper Chehalis River Basin in southwestern Washington.......2

2. Map showing land-cover classifications for the upper Chehalis River Basin, southwestern Washington.

3. Map showing mean annual precipitation, estimated from DAYMET precipitation data for the upper Chehalis River Basin, southwestern Washington, October 2001-September 2015

4. Map showing hydrologic soil group for the upper Chehalis River Basin, southwestern Washington.

5. Map showing available water capacity for the upper Chehalis River Basin, southwestern Washington.

6. Graph showing estimates of water-budget components calculated by Soil-Water-Balance model of the upper Chehalis River Basin, southwestern Washington, water years 2001-15

7. Map showing distribution of groundwater and surface-water withdrawals by Group A public-water supply systems, upper Chehalis River Basin, southwestern Washington, water years 2001-15

8. Map showing distribution of groundwater withdrawals by Group B public-water supply systems and self-supply domestic wells, upper Chehalis River Basin, southwestern Washington, water years 2001-15.

9. Graph showing comparison of mean base flow estimated by streamflow hydrograph-separation and analysis computer program and recharge estimated by Soil-Water-Balance model, upper Chehalis River Basin, southwestern Washington, water years 2001-15

10. Map showing mean annual recharge estimated by the Soil-Water-Balance model, upper Chehalis River Basin, southwestern Washington, water years 2001-15. 


\section{Figures-Continued}

11. Map showing difference in precipitation in the upper Chehalis River Basin, southwestern Washington, between water year 2015 and the average of water years 2001-15...

12. Map showing mean annual recharge estimated by the Soil-Water-Balance model for the upper Chehalis River Basin, southwestern Washington, water year 2015

\section{Tables}

1. Soil-Water-Balance model lookup table for runoff-curve numbers and root zone...........8

2. Estimates of water-budget components describing the fate of precipitation for the upper Chehalis River Basin, southwestern Washington, averaged for water years 2001-15

3. Estimates of mean annual water-budget components describing the fate of recharge for the upper Chehalis River Basin, southwestern Washington

\section{Conversion Factors}

U.S. customary units to International System of Units

\begin{tabular}{lll}
\hline \multicolumn{1}{c}{ Multiply } & By & \multicolumn{1}{c}{ To obtain } \\
\hline inch (in.) & Length & \\
foot (ft) & 2.54 & centimeter $(\mathrm{cm})$ \\
& 0.3048 & meter $(\mathrm{m})$ \\
\hline acre & Area & \\
square mile $\left(\mathrm{mi}^{2}\right)$ & 0.4047 & hectare $(\mathrm{ha})$ \\
\hline & 2.590 & square kilometer $\left(\mathrm{km}^{2}\right)$ \\
\hline inch per day (in/d) & Flow rate & \\
inch per year (in/yr) & 25.4 & millimeter per day $(\mathrm{mm} / \mathrm{d})$ \\
foot per year (ft/yr) & 25.4 & millimeter per year $(\mathrm{mm} / \mathrm{yr})$ \\
cubic foot per second $(\mathrm{ft} / \mathrm{s})$ & 0.3048 & meter per year $(\mathrm{m} / \mathrm{yr})$ \\
million gallons per year $(\mathrm{Mgal} / \mathrm{yr})$ & 0.02832 & cubic meter per second $\left(\mathrm{m}^{3} / \mathrm{s}\right)$ \\
\hline
\end{tabular}

International System of Units to U.S. customary units

\begin{tabular}{lccc}
\hline & Bultiply & By & To obtain \\
\hline & Length & \\
\hline meter $(\mathrm{m})$ & 3.281 & foot $(\mathrm{ft})$ & \\
\hline
\end{tabular}




\title{
Datums
}

Vertical coordinate information is referenced to the North American Vertical Datum of 1988 (NAVD 88).

Horizontal coordinate information is referenced to the North American Datum of 1983 (NAD 83).

Altitude, as used in this report, refers to distance above the vertical datum.

\section{Abbreviations}

\author{
APWL accumulated potential water loss \\ NLCD National Land Cover Database \\ SSURGO Natural Resources Conservation Service Soil Survey Geographic \\ SWB Soil-Water-Balance \\ USGS U.S. Geological Survey \\ WY water year
}





\title{
Water Budget of the Upper Chehalis River Basin, Southwestern Washington
}

\author{
By Andrew S. Gendaszek and Wendy B. Welch
}

\begin{abstract}
Groundwater and surface water collectively supply the domestic, agricultural, and industrial needs of the 895-square mile upper Chehalis River Basin upstream of Grand Mound, Washington, while providing streamflow for fish and other aquatic species in the Chehalis River and its tributaries. To support sustainable water management decision-making, a water budget (including precipitation, interception, groundwater recharge, surface runoff, and groundwater pumping) was developed for the upper Chehalis River Basin during October 2001-September 2015. Waterbudget components were estimated from the U.S. Geological Survey Soil-Water-Balance (SWB) model except for groundwater pumping, which was estimated from public water purveyor records, annual system data from the Washington State Department of Health, census population data, and water-use estimates. Groundwater recharge estimated from the SWB model was compared to base flow, a proxy for groundwater recharge, independently estimated from separation of the hydrograph recorded by the U.S. Geological Survey streamgage at the outlet of the basin. Mean annual precipitation for the basin was estimated at 72.6 inches, of which 35 percent was lost to evapotranspiration, 30 percent was recharged to groundwater, 30 percent was surface runoff, and 5 percent was lost to interception. SWB model estimates of groundwater recharge were 17 percent less than estimates of base flow from hydrograph separation. Groundwater pumpage in the basin was estimated at 1 percent of groundwater recharge estimated by SWB and 0.8 percent of base flow estimated by hydrograph separation. These estimates form a
\end{abstract}

baseline for understanding future changes to components of water use and may be used to inform numerical groundwater models to support sustainable management of water resources in the upper Chehalis River Basin.

\section{Introduction}

The Chehalis River, upstream of Grand Mound, Washington, drains an 895- $\mathrm{mi}^{2}$ area of Lewis, Thurston, and Pacific Counties in southwestern Washington State, including part of the Willapa Hills and the foothills of the Cascade Range (fig. 1). The water supply for people, fish, and wildlife is met in this geographical area (hereinafter referred to as the upper Chehalis River Basin) through a combination of groundwater and surface-water features including rivers, wetlands, and springs. Groundwater generally discharges to the Chehalis River and its tributaries from underlying aquifers (Ely and others, 2008), but also is recharged through losing stream reaches depending on the hydraulic relation between rivers and the underlying aquifers (Gendaszek, 2011). To sustainably manage future water resources for residential, industrial, and agricultural users while maintaining adequate water supply for fish and other wildlife, water managers in the upper Chehalis River Basin need to account for individual components of the hydrologic cycle through a water budget. In addition to basin-averaged water-budget components, the spatial distribution of groundwater recharge is an important boundary condition for the future development of a numerical groundwater-flow model to inform management of water resources of the upper Chehalis River Basin. 


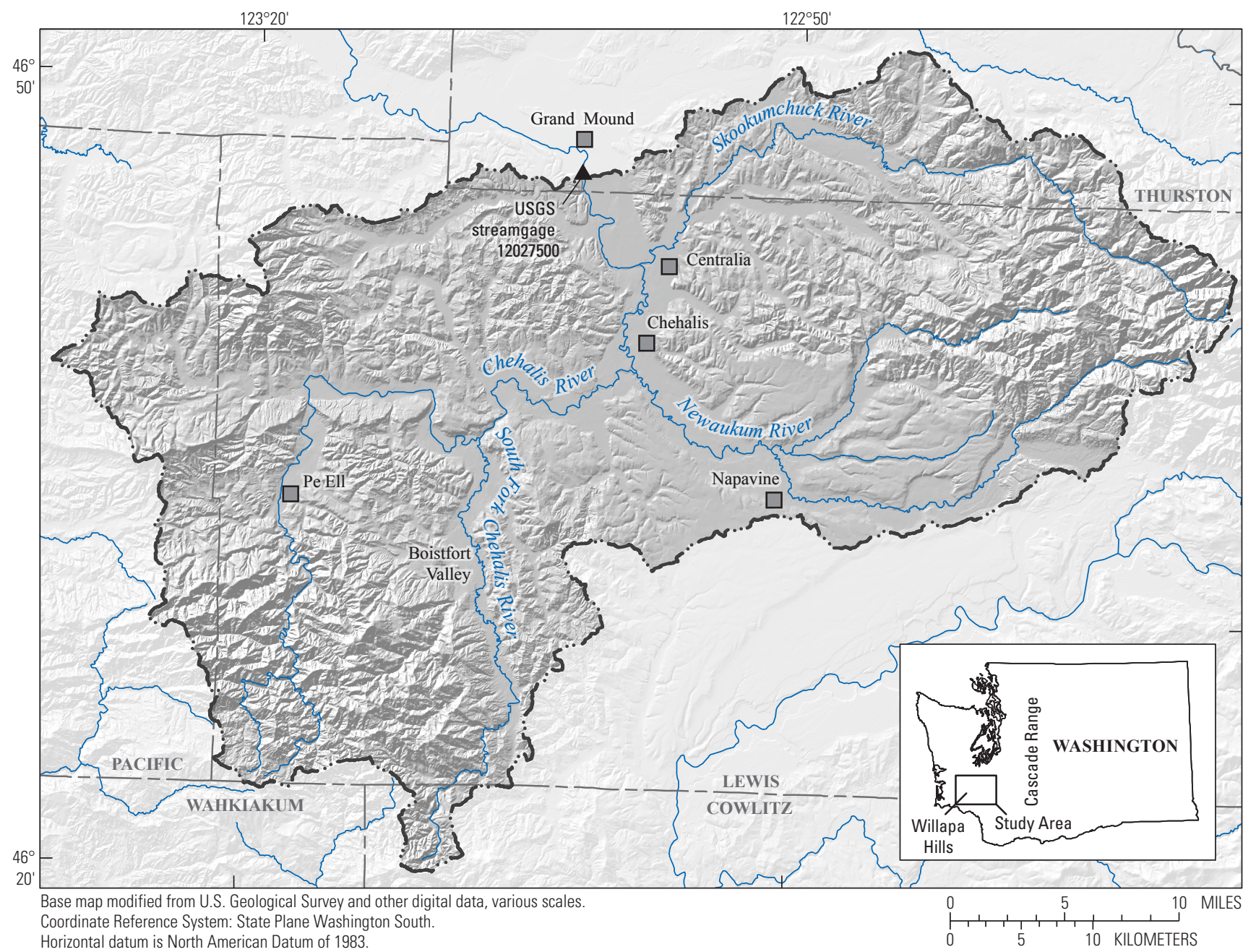

Figure 1. Location of upper Chehalis River Basin in southwestern Washington.

\section{Purpose and Scope}

The purpose of this report is to describe an accounting of water-budget components for the upper Chehalis River Basin. Mean annual water-budget components were calculated for the 15 years starting in water year ${ }^{1}$ (WY) 2001 through the end of WY 2015, a period selected because of the availability of input data and to account for inter-annual variability. Mean annual water-budget components were then compared to waterbudget components calculated during a drought year (WY 2015) to examine the effect of drought conditions on recharge. The water budget presented in this report informs ongoing efforts by the U.S. Geological Survey (USGS) to characterize the groundwater-flow system (Gendaszek, 2011) and groundwater/surface-water interactions (Ely and others, 2008) in the Chehalis River Basin in preparation for development of a numerical groundwater-flow model.

\section{Description of Study Area}

Most residential, industrial, and agricultural development and demand for water in the upper Chehalis River Basin are restricted to the valleys of the Chehalis River and its primary tributaries, the Newaukum and Skookumchuck Rivers (Gendaszek, 2011; fig. 2). These valleys dissect forested uplands, which have some rural residential development. The cities of Centralia, Chehalis, and Napavine meet their watersupply requirements with municipal public-water systems, whereas rural water users typically are self-supplied or supplied by smaller public-water systems.

Groundwater typically is pumped from unconsolidated alluvial and glacio-fluvial aquifers in the valleys of the Chehalis River and its tributaries (Gendaszek, 2011). These aquifers are confined locally by low-permeability hydrogeologic units consisting of unconsolidated fine-grained

\footnotetext{
${ }^{1}$ The 12 -month period from October 1, for any given year, through September 30 of the following year. The water year is designated by the calendar year in which it ends.
} 


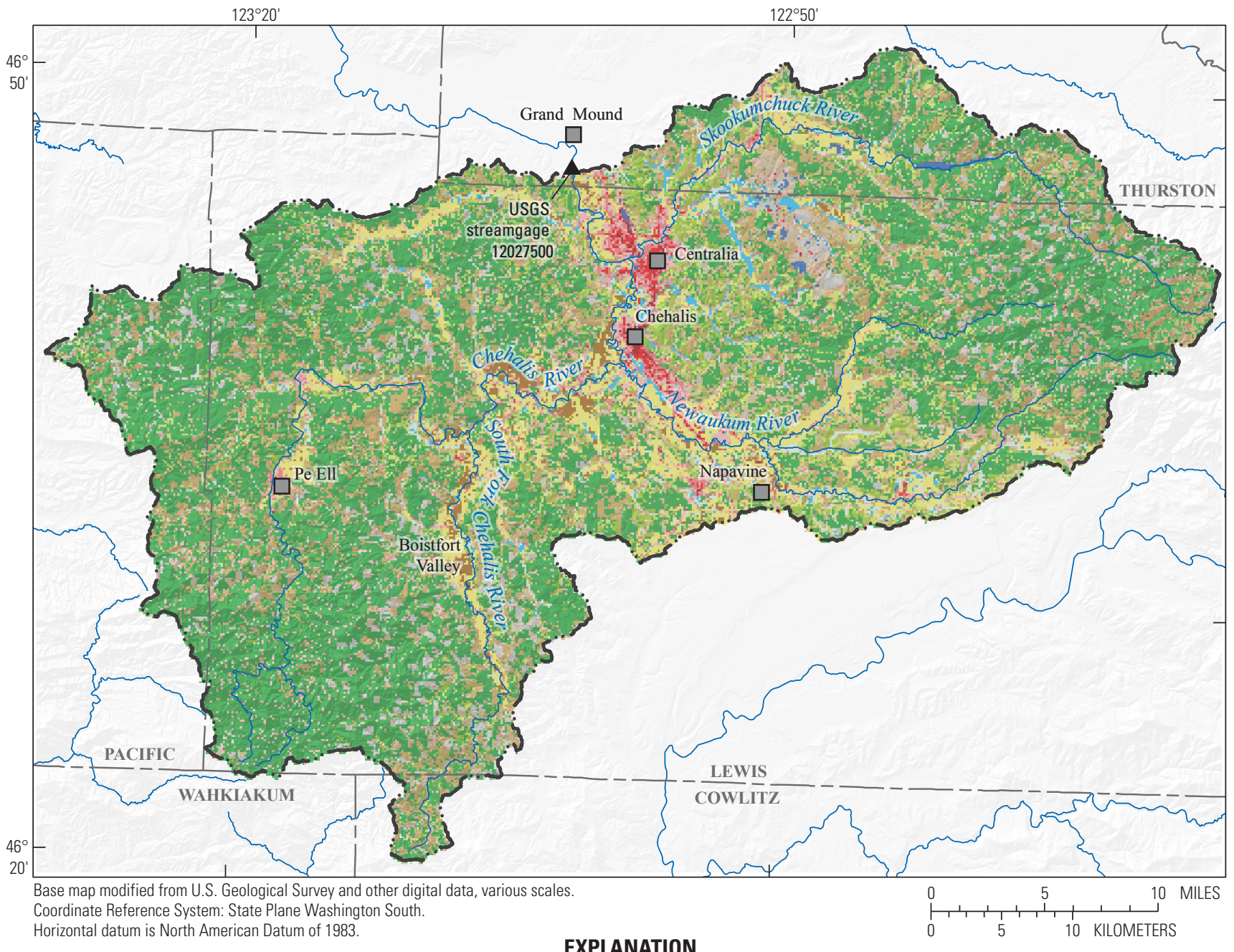

Coordinate Reference System: State Plane Washington South.
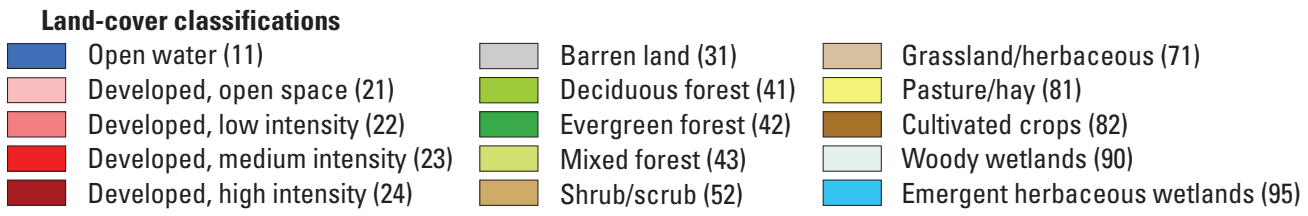

Figure 2. Land-cover classifications for the upper Chehalis River Basin, southwestern Washington. Source: 2001 National Land Cover Database (Homer and others, 2007).

sediments of alluvial and lacustrine origin. Some groundwater in rural upland areas is pumped from bedrock, but yields are minimal and pumping is limited to self-supply for domestic water use.

The climate of the upper Chehalis River Basin is characterized by cool, wet winters and warm, dry summers. Altitude of the basin ranges from a low of $124 \mathrm{ft}$ at the outlet of the basin at Grand Mound to a high of 3,825 ft in the foothills of the Cascade Range. Precipitation falls primarily as rain during autumn and winter. Mean annual precipitation averaged over the upper Chehalis River Basin was 72.6 in. and ranged from an annual mean of less than 50 in. in the northern part of the basin around the city of Centralia to more than $140 \mathrm{in}$. at the higher altitudes of the basin (DAYMET precipitation data averaged during WYs 2001-15; Thornton and others, 2017; fig. 3). Mean annual precipitation for the upper Chehalis River Basin during October 2001-September 2015 was estimated from DAYMET precipitation data (Thornton and others, 2017). 


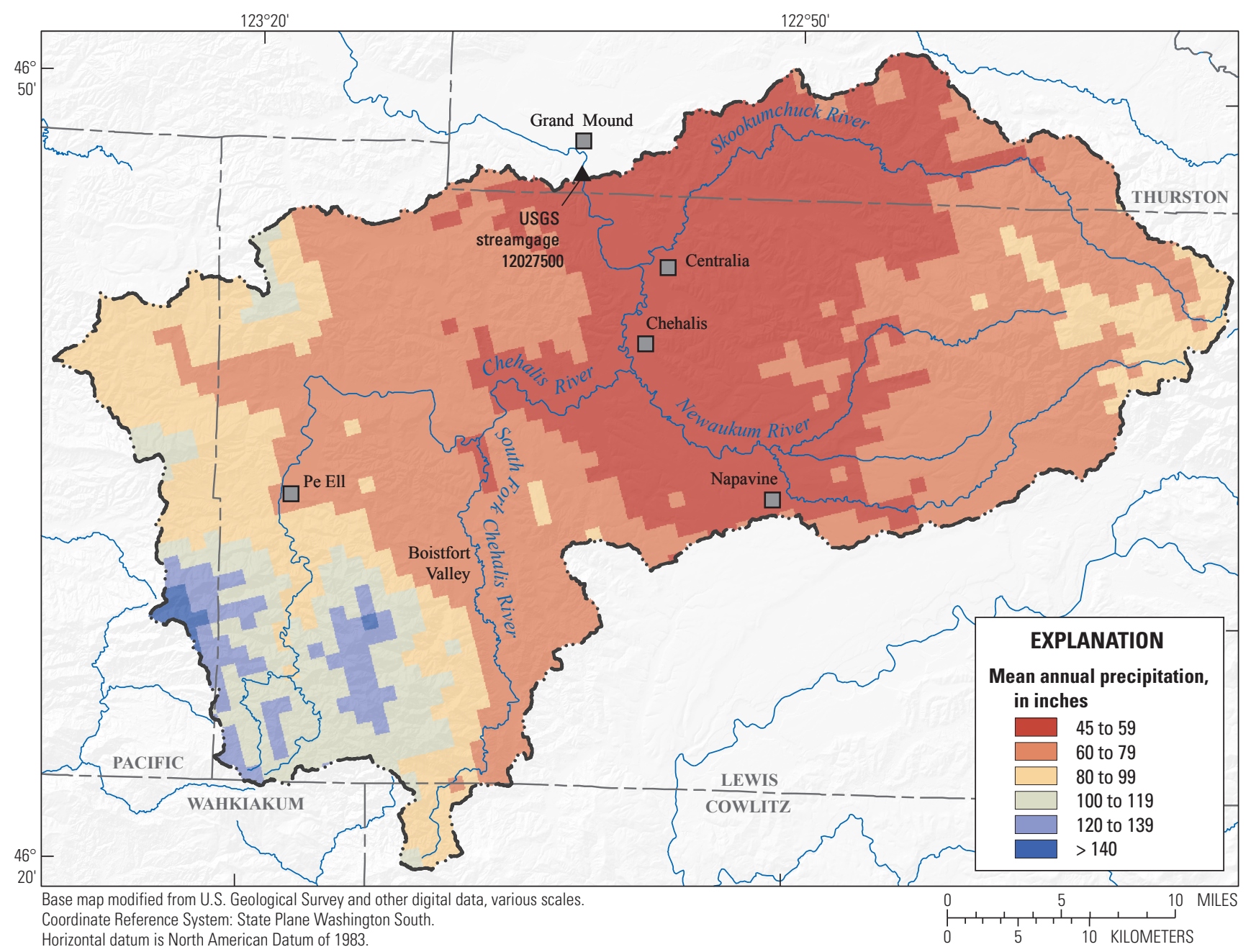

Figure 3. Mean annual precipitation, estimated from DAYMET precipitation data (Thornton and others, 2017), for the upper Chehalis River Basin, southwestern Washington, October 2001-September 2015.

\section{Water Budget}

A water budget for a hydrologic system equates inflows of water to the system $\left(\mathrm{Q}_{\text {in }}\right)$ to outflows of water $\left(\mathrm{Q}_{\text {out }}\right)$ and changes in storage $(\Delta \mathrm{S})$ :

$$
\mathrm{Q}_{\text {in }}=\mathrm{Q}_{\text {out }}+\Delta \mathrm{S} \text {. }
$$

Changes in storage may occur over short inter-annual to monthly timescales, but over the long term, steady-state conditions generally are present where inflows to the hydrologic system are balanced by outflows. Inflows to a hydrologic system can include precipitation, surface-water inflows, and groundwater inflows from adjacent hydrogeologic units. Outflows from a hydrologic system can include evapotranspiration, groundwater pumpage, and outflows of surface water and groundwater from the system. Water also moves within a hydrogeologic system between surface and groundwater storage through hydrologic processes, including groundwater recharge and groundwater/surface-water exchange between aquifers and rivers and lakes. 


\section{Methods}

\section{Precipitation, Recharge, Evapotranspiration, Interception, and Outflow-Soil Water Balance}

A Soil-Water-Balance (SWB) model (SWB version 1.0.1; U.S. Geological Survey, 2016) was developed for the study area to estimate the spatial distribution of recharge, evapotranspiration, interception, and outflow as surface runoff during WYs 2001-15 at a daily time step (Dripps and Bradbury, 2007; Westenbroek and others, 2010). The daily spatial distribution of precipitation was supplied as an input to the SWB model. A 22-month model initialization period from January 1999 to September 2000 was completed prior to the WY 2001015 study period to estimate antecedent conditions including soil moisture and snow cover. The study area was divided into 500-ft grid cells consisting of 378 rows and 546 columns. Cells outside the Chehalis River watershed upstream of the USGS streamgage at Grand Mound were inactive, which resulted in a total of 100,142 active model cells. The $500-\mathrm{ft}$ grid cell resolution was selected to be comparable to current (2018) regional-scale numerical groundwater-flow models of western Washington under development by the USGS in western Washington.

SWB calculates the water budget for each cell at a daily time step through a modified Thornthwaite-Mather soil-waterbalance approach (Thornthwaite and Mather, 1955, 1957):

$$
\begin{aligned}
& \text { Recharge }=\text { Rainfall }+ \text { Snowmelt }+ \text { Inflow } \\
& - \text { Interception }- \text { Outflow }- \text { Evapotranspiration } \\
& -\Delta \text { Soil Moisture. }
\end{aligned}
$$

Spatially distributed inputs to the SWB model included daily precipitation, daily minimum temperature, daily maximum temperature, land cover data, overland flow direction, and two related soil properties - hydrologic soil group and available soil-water capacity. For each model cell, input data for each of these properties were resampled to a $500-\mathrm{ft}$ grid cell size and aligned and projected to a common grid cell for the SWB model. Daily precipitation, minimum temperature, and maximum temperature for WYs 1999-15 were assigned to each model cell from the DAYMET (Thornton and others, 2017) database. Land-cover classification was obtained from the Multi-Resolution Land Characteristics Consortium's 2001 National Land Cover Database (NLCD; Homer and others, 2007). The NLCD classifies the conterminous United States into 16 land-cover classes at a 30-m resolution, which was clipped to the model extent and resampled to a $500-\mathrm{ft}$ cell size (fig. 2). Fifteen NLCD land-cover classes occur in the model extent. Hydrologic soil groups and available water capacity data were obtained from the Natural Resources
Conservation Service Soil Survey Geographic (SSURGO) database (Natural Resources Conservation Service, 2014), clipped to the extent of the model, and resampled to the model 500-ft grid size. Soils in the SSURGO database are classified into four hydrologic soil groups (A, B, C, and D), which range from group A soils that have a high-infiltration and low-runoff capacity to group D soils that have a low-infiltration and highrunoff capacity (fig. 4). SSURGO also specifies the available water capacity, defined as the amount of water that the soil can hold for each soil series at several soil depths. For the model, the SSURGO available water capacity was averaged over the top 39 in. of soil and assigned to each 500-ft grid cell (fig. 5).

Calculation of water-budget components by SWB for each model cell is summarized here and described in detail by Westenbroek and others (2010). Daily meteorological data (including precipitation, minimum temperature, and maximum temperatures) were specified for each model cell; depending on the temperature, precipitation fell as either rain or snow. If precipitation occurred when the temperature was lower than the freezing point, the model calculated precipitation as snow and it accumulated at each model cell until the temperature exceeded the freezing point. Above the freezing point, the snow melted and then that water equivalent became available for evapotranspiration, recharge, and runoff. The SWB flow routing of surface-runoff option was not used because of the resolution of this model was too large to adequately represent routing of surface water; therefore, we assumed that surface runoff that left a cell immediately left the model area and that the inflow term for each cell was zero. As a result, recharge estimated may have been underestimated by the model because surface runoff did not have an opportunity to recharge within downstream cells. Rainfall that did not reach the ground because of vegetation was modeled as interception loss. The interception rate was specified for each land-use type for the growing and dormant seasons. Outflow from each cell was calculated using the NRCS curve number rainfall-runoff relation (Cronshey and others, 1986) and immediately exited the model domain as surface runoff. Potential evapotranspiration for each cell was calculated using the Hargreaves-Samani method (Hargreaves and Samani, 1985), which uses daily minimum and maximum temperature data provided by DAYMET for this model. Changes in soil moisture were calculated by first subtracting precipitation from potential evapotranspiration. If potential evapotranspiration exceeded precipitation, then there was a potential deficiency of water, which was tracked by the accumulated potential water loss (APWL) term. Soil moisture was estimated from the APWL using the non-linear relation described by Thornwaite and Mather (1957). Conversely, if precipitation exceeded potential evapotranspiration, soil moisture increased and, if moisture exceeded the maximum water-holding capacity, the excess water became recharge. 


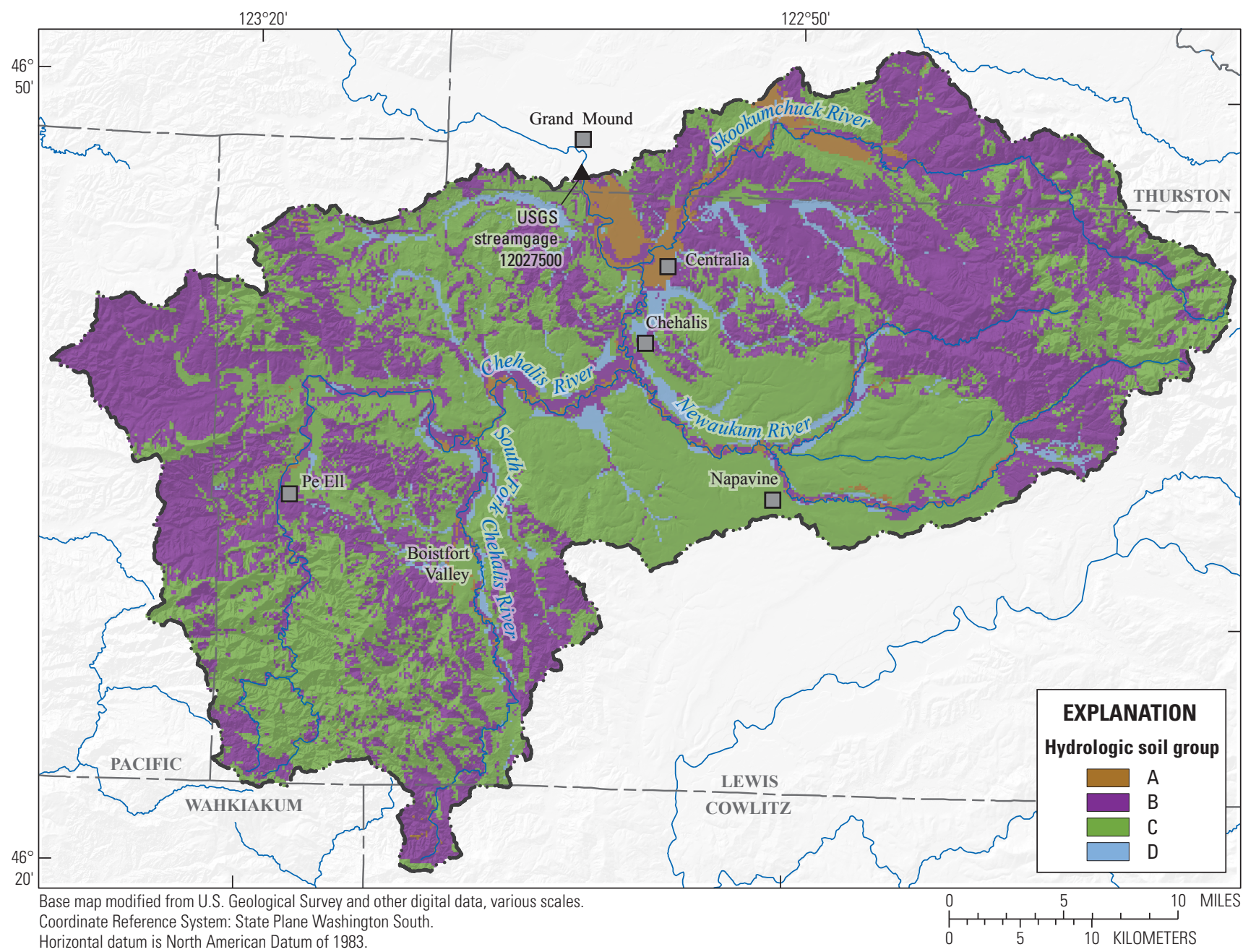

Figure 4. Hydrologic soil group for the upper Chehalis River Basin, southwestern Washington. Soil classification ranges from Group A soils with high infiltration capacity and low overland flow potential to Group D soils with low infiltration capacity and high overland flow potential. Data from Natural Resources Conservation Service (2014).

For each unique land-cover/hydrologic soil group combination, runoff-curve numbers, vegetation routing depths, interception rates, and maximum daily recharge values were defined in a lookup table used by SWB. The lookup table used for the upper Chehalis River Basin SWB model was populated with values used by Tillman (2015). Runoff-curve numbers obtained from the NRCS National Hydrology Handbook (Natural Resources Conservation Service, 2004) and Westenbroek and others (2010), and root zone depths obtained from Canadell and others (1996) and Westenbroek and others (2010), are presented in table 1.

Interception rates and maximum daily infiltration rates were obtained from Westenbroek and others (2010). An interception rate of 0.0835 in. was applied to all land-cover types during the growing season except for open water, barren land, and emergent herbaceous wetlands (for which the interception rate was 0 in.); during the dormant season, the interception rate was 0 in. (Tillman, 2015). For all land-cover types, maximum recharge rates were set to $2 \mathrm{in} / \mathrm{d}$ for hydrologic soil group A, $0.6 \mathrm{in} / \mathrm{d}$ for hydrologic soil group B, $0.24 \mathrm{in} / \mathrm{d}$ for hydrologic soil group $\mathrm{C}$, and $0.12 \mathrm{in} / \mathrm{d}$ for hydrologic soil group D (Tillman, 2015).

\section{Surface Runoff and Base Flow-Hydrograph Separation}

Hydrograph separation was used to partition streamflow into its two components - base flow from groundwater discharge and surface runoff from overland flow. Groundwater discharge to streams, or base flow, has often been used to approximate groundwater recharge (Risser and others, 2005). 


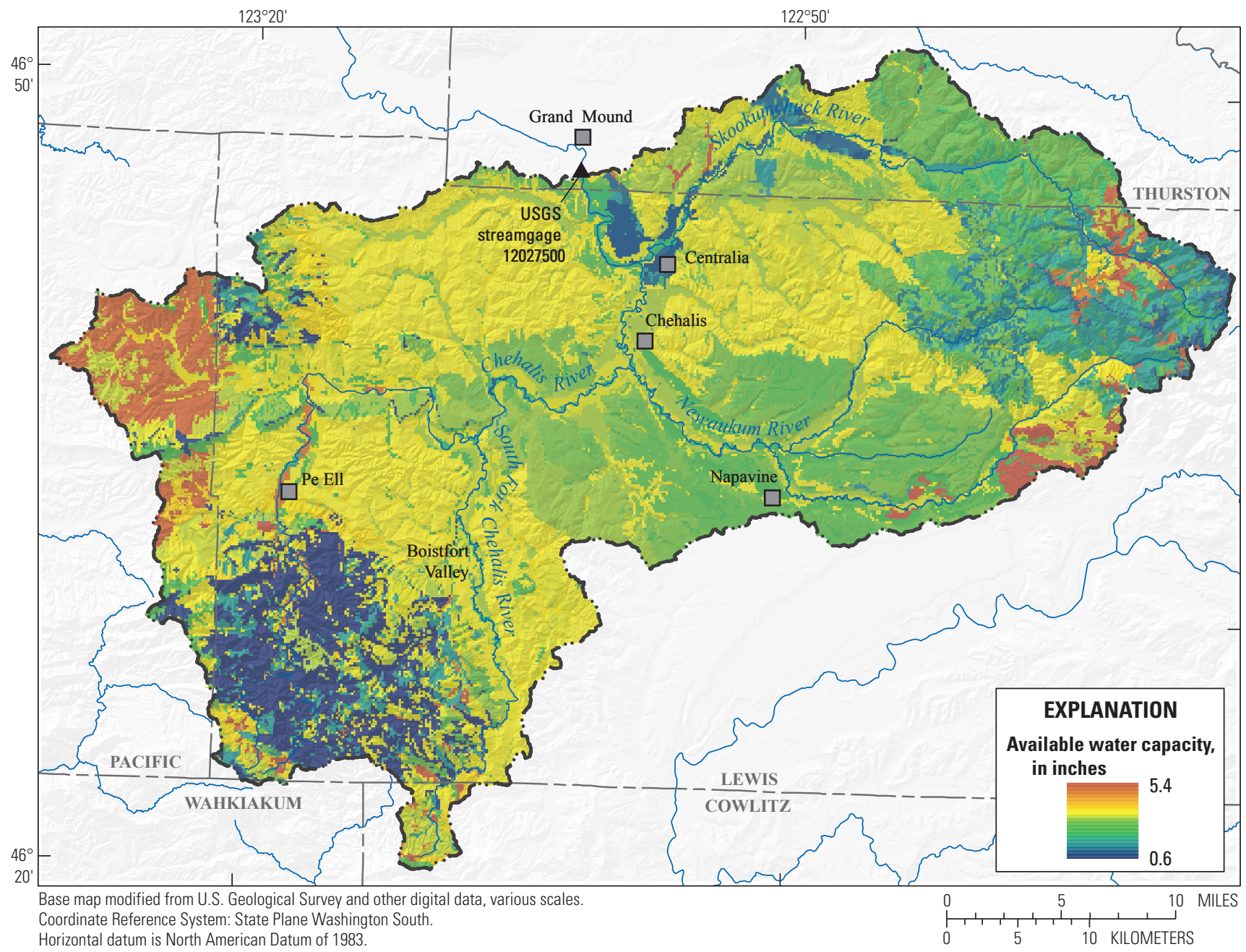

Figure 5. Available water capacity for the upper Chehalis River Basin, southwestern Washington. Data from Natural Resources Conservation Service (2014).

Hydrograph separation assumes losses of groundwater due to other processes including evapotranspiration from riparian vegetation, exchange with underlying aquifers, and groundwater exports from the basin due to pumping or underflow are minimal. Many methods have been developed to differentiate streamflow into these two components based on graphical, chemical, and isotopic methods (Healy, 2010). Although chemical and isotopic base flow separation methods such as specific conductance or isotopic data offer improvements over graphical separation methods (Burns, 2002), only streamgage records were available in the upper Chehalis River Basin. Therefore, graphical methods were used to estimate base flow in the upper Chehalis River Basin. The accuracy of graphical methods, however, is limited. For example, Stewart and others (2007) reported an accuracy of base flow estimated by graphical separation of as much as a factor of two for basins in the Southeastern United States.
The daily mean discharge hydrograph recorded by the streamgage at the outlet of the upper Chehalis River Basin (USGS streamgage 12027500) during WYs 2001-15 was separated into base flow and surface runoff by using the streamflow hydrograph-separation and analysis computer program (HYSEP; Sloto and Crouse, 1996). HYSEP includes three methods for separating streamflow into base-flow and surface-runoff components by using geometric algorithms including the fixed interval, sliding interval, and localminimum algorithms. Following Smith and Westenbroek (2015), an estimate averaged from the three streamflow hydrograph separation methods calculated by HYSEP was used in subsequent analyses in this report to avoid potential biases associated with choosing a single method. 
Table 1. Soil-Water-Balance model lookup table for runoff-curve numbers and root zone.

[From Tillman (2015) and references within. Abbreviations: HSG, hydrologic soil group; NLCD, National Land Cover Database; ft, foot]

\begin{tabular}{|c|c|c|c|c|c|c|c|c|c|}
\hline \multicolumn{2}{|r|}{ NLCD land cover } & \multicolumn{4}{|c|}{ Curve No. } & \multicolumn{4}{|c|}{ Depth of root zone (ft) } \\
\hline 11 & Open water & 100 & 100 & 100 & 100 & 0 & 0 & 0 & 0 \\
\hline 22 & Developed, low intensity & 77 & 86 & 91 & 94 & 8.53 & 8.53 & 8.53 & 8.53 \\
\hline 23 & Developed, medium intensity & 89 & 92 & 94 & 95 & 8.53 & 8.53 & 8.53 & 8.53 \\
\hline 24 & Developed, high intensity & 98 & 98 & 98 & 98 & 8.53 & 8.53 & 8.53 & 8.53 \\
\hline 41 & Deciduous forest & 32 & 48 & 57 & 63 & 9.5 & 9.5 & 9.5 & 9.5 \\
\hline 42 & Evergreen forest & 39 & 58 & 73 & 80 & 12.8 & 12.8 & 12.8 & 12.8 \\
\hline 43 & Mixed forest & 46 & 60 & 68 & 74 & 11.15 & 11.15 & 11.15 & 11.15 \\
\hline 52 & Shrub/scrub & 49 & 68 & 79 & 84 & 3.5 & 3.5 & 3.5 & 3.5 \\
\hline 71 & Grassland/herbaceous & 64 & 71 & 81 & 89 & 8.53 & 8.53 & 8.53 & 8.53 \\
\hline 81 & Pasture/hay & 49 & 69 & 79 & 84 & 8.53 & 8.53 & 8.53 & 8.53 \\
\hline
\end{tabular}

\section{Estimation of Groundwater Pumping}

Groundwater pumping by public-supply, self-supply, and irrigation wells in the upper Chehalis River Basin was estimated by using a combination of reported pumping rates by water purveyors, annual system data from the Washington State Department of Health, census population data and domestic water-use estimates, and irrigated acreage and irrigation application rates. Twenty-four Group A publicwater systems, which serve 15 or more connections or more than 25 people, served an estimated total of 30,963 people in the upper Chehalis River Basin as of 2010. The largest of the public-water systems, the City of Centralia, supplied monthly groundwater pumpage records from 2000 to 2017. Annual groundwater pumpage for the remaining Group A public-water supply systems was estimated by the annual totals reported to the Washington State Department of Health (2018). In addition to withdrawals from groundwater, several public-supply systems in the basin obtain water from surface water from the Chehalis River and its tributaries. The spatial distribution of groundwater pumpage by Group A publicsupply systems was determined from overlaying 2010 census blocks on the public-water supply service areas (Washington State Office of Financial Management, 2018); the residual census blocks that were not assigned to Group A public-supply systems were assumed to be either self-supplied or part of a Group B system, which serves fewer than 15 connections and 25 people. Census blocks, which range in size depending on factors including population density, are the smallest geographic unit for which population is tabulated by the U.S. Census.

As of 2010, self-supply domestic and Group B wells serve an estimated population of 23,896 people. Unlike Group A systems, Group B and self-supply systems were not required to report pumpage rates to the Washington State Department of Health; therefore, water-use estimates were based on 2005 and 2010 per-capita water-use rates for Lewis and Thurston counties reported by Lane (2009) and Lane and Welch (2015). Total irrigation withdrawals were estimated by determining the area of irrigated agricultural land from the Washington State Department of Agriculture agricultural land use geodatabase (Washington State Department of Agriculture, 2018) and multiplying by the irrigation application rate for Lewis County (17.04 in/yr) reported by Lane and Welch (2015). Irrigation was separated into its groundwater component by multiplying the fraction of Lewis County irrigation from groundwater pumpage (0.55) reported by Lane and Welch (2015). 


\section{Water Budget Results}

Components describing the fate of precipitation including surface runoff, evapotranspiration, groundwater recharge, interception, and change in soil moisture are reported from SWB model output; the sum of these components equals total precipitation supplied as an input to the SWB model. The average estimate of water-budget components from WYs 2001-15 is reported in table 2, and water-budget components for individual water years are presented in figure 6. On average, SWB estimated that during WYs 2001-15, nearly equal parts of the gross precipitation were recharged to groundwater (22.0 in.; 30.3 percent), left as surface runoff (21.6 in.; 29.8 percent), or were evapotranspired (25.6 in.; 35.3 percent). Vegetation intercepted less water (3.6 in.; 5.0 percent), with higher rates of interception occurring in the summer when deciduous vegetation has leaves. Changes in soil moisture were almost negligible, with an overall change in soil moisture of -0.2 in. during WYs $2001-15$ (-0.3 percent), indicating that soil moisture was nearly in steady state during this 15 -year period.

The fate of the groundwater recharge component of the water budget was calculated in two ways: (1) by using groundwater recharge estimated by the SWB model, and (2) by calculating groundwater recharge from base flow estimated by hydrograph separation. In the first case,
Table 2. Estimates of water-budget components describing the fate of precipitation for the upper Chehalis River Basin, southwestern Washington, averaged for water years 2001-15.

\begin{tabular}{lcc}
\hline \multicolumn{1}{c}{ Fate of precipitation } & Inches per year & Percentage of total \\
\hline Surface runoff & 21.6 & 29.8 \\
Evapotranspiration & 25.6 & 35.3 \\
Groundwater recharge & 22.0 & 30.3 \\
Interception & 3.6 & 5.0 \\
Change in soil moisture & -0.2 & -0.3 \\
Total precipitation & 72.6 & 100.0 \\
\hline
\end{tabular}

natural discharge was calculated as the difference between groundwater recharge estimated by SWB and the sum of groundwater pumpage estimated from Groups A and B, domestic self-supply, and irrigation wells. In the second case, natural discharge was obtained from the base-flow component of hydrograph separation and summed with groundwater pumpage estimated from Groups A and B, domestic selfsupply, and irrigation wells to obtain total groundwater recharge. In each case, it was recognized that natural discharge included groundwater discharge to streams as well as springs and other surface-water features, which ultimately leaves the basin through surface-water flow or evapotranspiration.

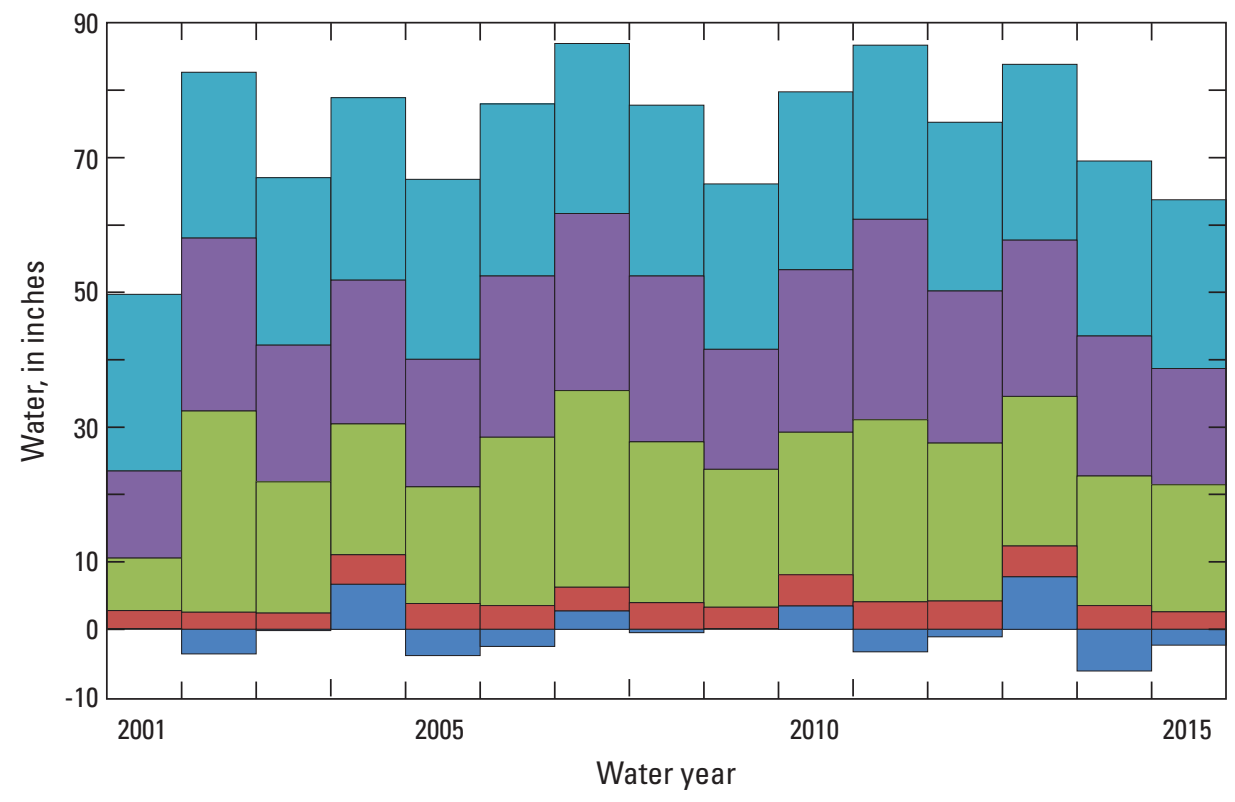

\section{EXPLANATION}

Water-budget components Evapotranspiration Groundwater recharge Surface runoff Interception Change in soil moisture

Figure 6. Estimates of water-budget components calculated by Soil-Water-Balance model of the upper Chehalis River Basin, southwestern Washington, water years 2001-15. 
Mean annual groundwater and surface-water withdrawals were determined for public-supply systems, domestic selfsupply water users, and irrigators. Group A public-water systems obtain water from both groundwater pumpage and surface-water withdrawals, whereas Group B water systems and domestic self-supply wells solely obtain water from groundwater. During WYs 2001-15, Group A systems serving Chehalis, Pe Ell, and Boistfort Valley obtained a total of $794 \mathrm{Mgal} / \mathrm{yr}$ of water from surface-water sources including the Chehalis River and its tributaries, which represented 45 percent of the total water supplied by Group A systems in the upper Chehalis River Basin. The remaining water supplied by Group A systems ( $974 \mathrm{Mgal} / \mathrm{yr}$ ) was pumped from wells (groundwater withdrawal; fig. 7). Group B and self-supply domestic wells were estimated to collectively withdraw $775 \mathrm{Mgal} / \mathrm{yr}$ (fig. 8). Averaged across the basin, these groundwater withdrawals were 0.06 and $0.05 \mathrm{in} / \mathrm{yr}$ for Group A wells and Group B/self-supply domestic wells, respectively. The total irrigated area of the upper Chehalis River Basin was estimated at 5,997 acres and irrigated at an estimated rate of $1.42 \mathrm{ft} / \mathrm{yr}$ (Lane and Welch, 2015). Averaged across the upper Chehalis River Basin, total irrigation was estimated at $0.18 \mathrm{in} / \mathrm{yr}$ with 55 percent of irrigation $(0.10 \mathrm{in} / \mathrm{yr})$ sourced from groundwater (Lane and Welch, 2015). The combined groundwater pumpage from Group A and B public supply, domestic self-supply, and irrigation wells was 0.21 in., which is 1 percent of groundwater recharge estimated by SWB and 0.8 percent of recharge estimated from base flow calculated from hydrograph separation by HYSEP (table 3-Group A well pumpage + Self-supply and Group B well pumpage + Irrigation well pumpage).

Mean annual discharge recorded at the USGS streamgage at the Chehalis River near Grand Mound (USGS streamgage 12027500 ) was $2,760 \mathrm{ft}^{3} / \mathrm{s}$, which equals $41.8 \mathrm{in}$. averaged over the $895-\mathrm{mi}^{2}$ area of the upper Chehalis River Basin. Estimates of the base-flow component of streamflow by the three hydrograph separation methods implemented by HYSEP were $23.8 \mathrm{in}$. (fixed interval), $26.5 \mathrm{in}$. (sliding interval), and 26.6 in. (local-minimum algorithms). The three-method average for the mean annual base-flow estimate was $25.6 \mathrm{in}$. $\left(1,690 \mathrm{ft}^{3} / \mathrm{s}\right)$, and the residual streamflow (16.2 in.; $\left.1,070 \mathrm{ft}^{3} / \mathrm{s}\right)$ was inferred to be sourced from surface runoff.

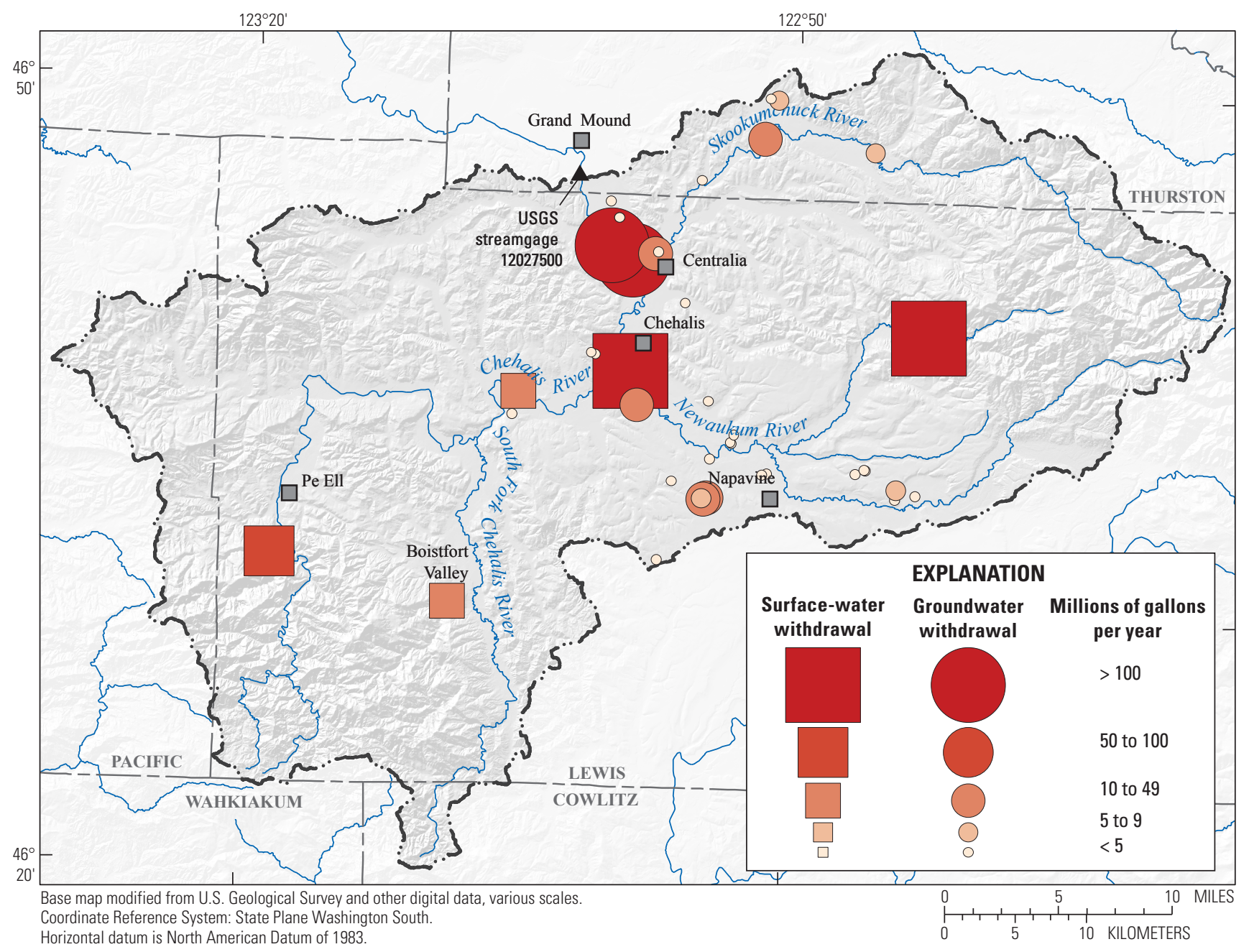

Figure 7. Distribution of groundwater and surface-water withdrawals by Group A public-water supply systems, upper Chehalis River Basin, southwestern Washington, water years 2001-15. 


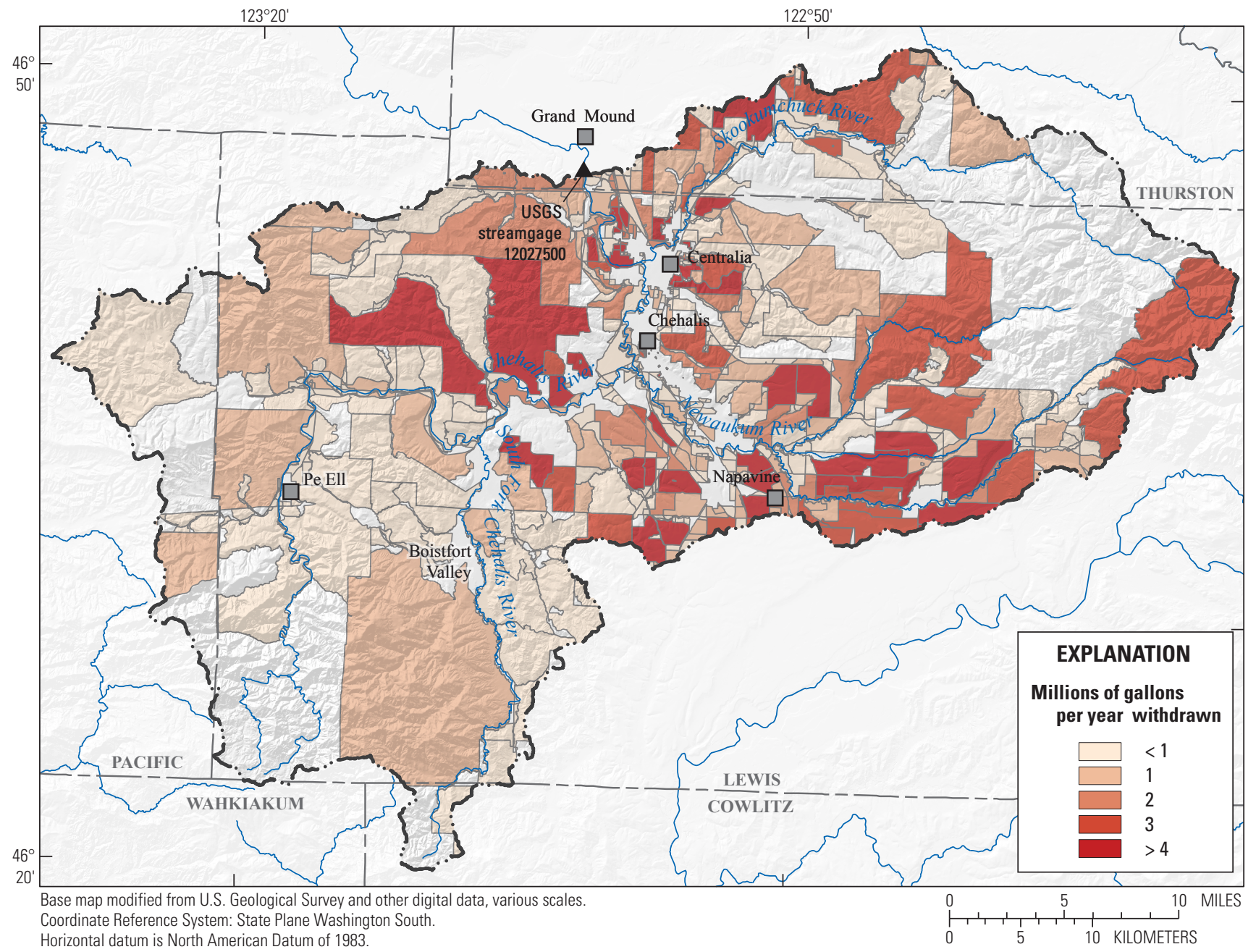

Figure 8. Distribution of groundwater withdrawals by Group B public-water supply systems and self-supply domestic wells, upper Chehalis River Basin, southwestern Washington, water years 2001-15.

Table 3. Estimates of mean annual water-budget components describing the fate of recharge for the upper Chehalis River Basin, southwestern Washington.

[HYSEP, streamflow hydrograph-separation and analysis computer program]

\begin{tabular}{|c|c|c|c|c|}
\hline \multirow[b]{2}{*}{ Fate of recharge } & \multicolumn{2}{|c|}{ Soil-Water-Balance model } & \multicolumn{2}{|c|}{ HYSEP base-flow separation } \\
\hline & $\begin{array}{c}\text { Inches per } \\
\text { year }\end{array}$ & $\begin{array}{c}\text { Percentage of } \\
\text { total }\end{array}$ & $\begin{array}{c}\text { Inches per } \\
\text { year }\end{array}$ & $\begin{array}{c}\text { Percentage of } \\
\text { total }\end{array}$ \\
\hline Natural discharge & 21.79 & 99.0 & 25.6 & 99.2 \\
\hline Group A well pumpage & 0.06 & 0.3 & 0.06 & 0.2 \\
\hline Self-supply and Group B well pumpage & 0.05 & 0.2 & 0.05 & 0.2 \\
\hline Irrigation well pumpage & 0.10 & 0.5 & 0.10 & 0.4 \\
\hline Total recharge & 22.0 & 100.0 & 25.81 & 100.0 \\
\hline
\end{tabular}




\section{Discussion}

Input of water into the upper Chehalis River Basin occurs primarily from precipitation in the absence of surface-water inputs or groundwater inflow, which is precluded by lowhydraulic conductivity bedrock that bounds major aquifers in the basin. Most precipitation falls as rain during autumn and winter, with some snow falling at higher elevations of the basin. The highest precipitation rates have occurred in areas of high topography, including the foothills of the Cascade Range and the Willapa Hills where mean annual precipitation exceeded 140 in.; precipitation rates were lowest in the lower elevations of the northern part of the upper Chehalis River Basin, near the city of Centralia, where less than 50 in. of precipitation fell (fig. 3). During a drought year (2015), mean annual precipitation was $61.4 \mathrm{in}$. or 15.4 percent less than the mean for WYs 2001-15.

Water primarily leaves the basin as evapotranspiration or surface-water outflow, assuming minimal groundwater discharge at the outlet of the basin where low-hydraulic conductivity bedrock largely confines the principal alluvial aquifers. A rough basin-scale water budget may be constructed by assuming that precipitation $(\mathrm{P})$ is the only input, evapotranspiration (ET) and surface-water discharge $\left(\mathrm{Q}_{\text {surface-water }}\right)$ are the only outputs, and that there are negligible changes in storage $(\Delta \mathrm{S})$ such that equation (1) becomes:

$$
\mathrm{P}=\mathrm{ET}+\mathrm{Q}_{\text {surface-water }} \text {. }
$$

A first-order estimate of evapotranspiration, therefore, may be determined by subtracting surface-water discharge from the basin (41.8 in.) from precipitation (72.6 in.), which equals $30.8 \mathrm{in}$. To further refine the water budget and determine the fate of groundwater recharge, constituents of the water budget were estimated using SWB, hydrograph separation, and analysis of water-use records and population data. The firstorder estimate of evapotranspiration calculated by equation 2 (30.8 in.) was 20 percent greater than the mean annual evapotranspiration estimated by SWB (25.6 in.).

Basin-averaged mean annual groundwater recharge estimated by the SWB model during WYs 2001-15 was 22 in. and broadly agreed with base flow estimated by hydrograph separation (fig. 9). During WYs 2001-15, base flow was an average of 17 percent greater than recharge. Natural discharge accounted for 99 percent of recharge, whereas the combined pumping from Groups A and B, domestic self-supply wells, and irrigation wells accounted for 1 percent of recharge. Recharge ranged from a mean of less than 10 to more than $50 \mathrm{in} / \mathrm{yr}$ across the upper Chehalis River Basin (fig. 10). These results are comparable to previously estimated recharge in other locations in western Washington including Puget Sound (Vaccaro and others, 1998) and Thurston County (Drost and others, 1999). Groundwater recharge generally was highest in areas of the upper Chehalis River Basin where precipitation was highest, such as the Willapa Hills and the foothills of the Cascade Range, but soil properties locally limited groundwater recharge rates.

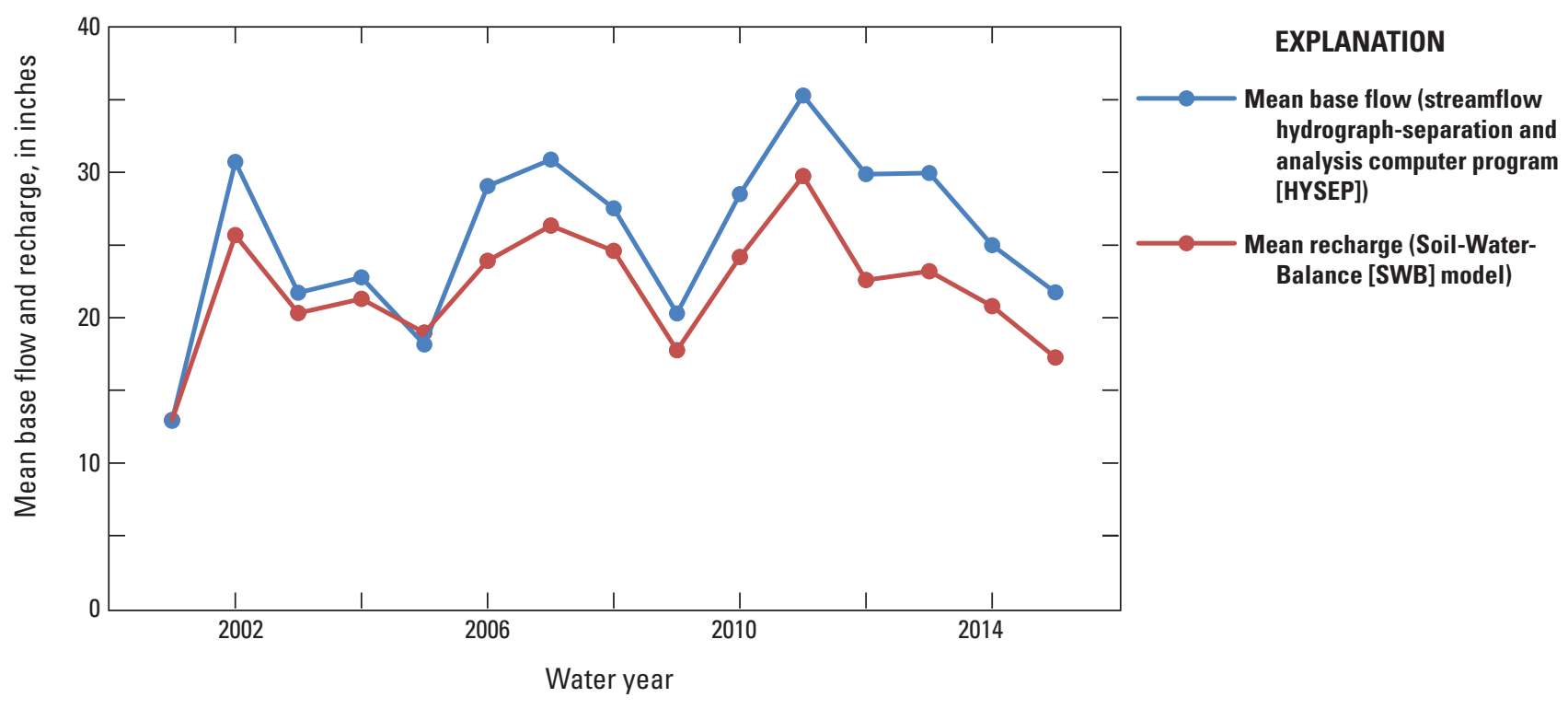

Figure 9. Comparison of mean base flow estimated by streamflow hydrograph-separation and analysis computer program and recharge estimated by Soil-Water-Balance model, upper Chehalis River Basin, southwestern Washington, water years 2001-15. 


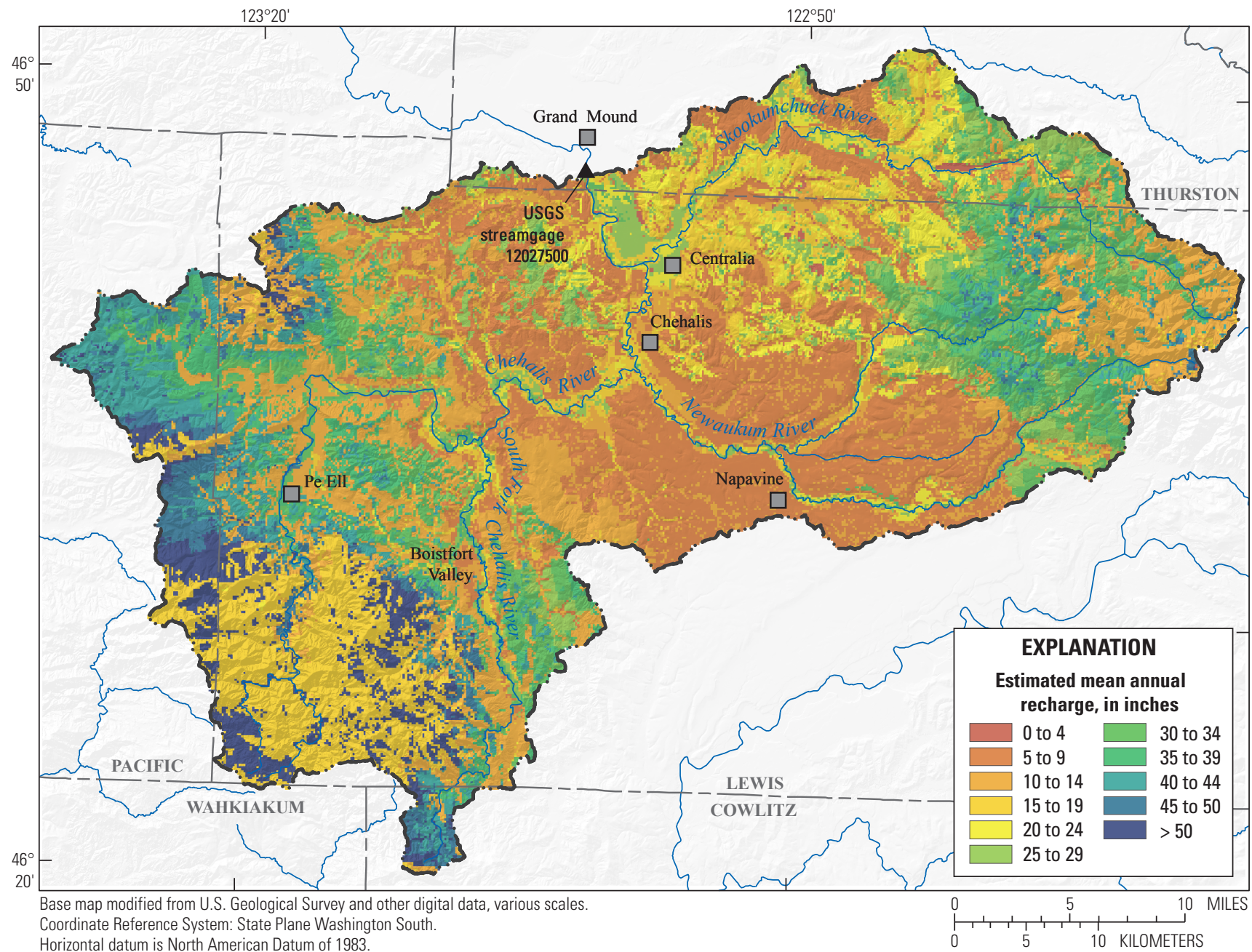

Figure 10. Mean annual recharge estimated by the Soil-Water-Balance model, upper Chehalis River Basin, southwestern Washington, water years 2001-15.

In the Willapa Hills, for example, groundwater recharge rates locally exceeded $50 \mathrm{in} / \mathrm{yr}$ where Group B soils occurred, but recharge rates were less than $20 \mathrm{in} / \mathrm{yr}$ in adjacent areas where Group C soils with comparatively low infiltration capacities occurred. The main Chehalis River valleys had relatively high recharge rates, locally exceeding $35 \mathrm{in} / \mathrm{yr}$ despite lower precipitation rates than the Willapa Hills where hydrologic soil groups A and B with relatively high infiltration capacities occurred. In areas of the valleys of the Chehalis River and its main tributaries, where hydrologic soil groups A and $\mathrm{B}$ with high infiltration capacities predominated, recharge was relatively high and locally exceeded $30 \mathrm{in} / \mathrm{yr}$. Where hydrologic soil groups $\mathrm{C}$ and $\mathrm{D}$ (which have low infiltration capacities and high surface-runoff potentials) coincided with areas of low precipitation such as the uplands of the central part of the upper Chehalis River Basin, mean annual recharge was limited to less than $10 \mathrm{in} / \mathrm{yr}$.
A comparison of recharge estimated during WY 2015 and WYs 2001-15 was made to examine the effect of drought conditions during WY 2015 on recharge. The difference in precipitation between WY 2015 and the average of WYs 2001-15 was not uniform, with 2015 being driest in the southwestern and central part of the upper Chehalis River Basin including the main population centers of Centralia, Chehalis, and Napavine, but wetter in the northeastern and northwestern parts of the basin (fig. 11). Basin-averaged groundwater recharge during the drought of WY 2015 was 17.2 in., or 21.8 percent less than the average of WYs 2001-15. Following changes in precipitation patterns between WY 2015 and the average of WYs 2001-15, groundwater recharge decreased over most of the upper Chehalis River Basin, but increased slightly in the northeastern and northwestern parts of the basin (fig. 12). 


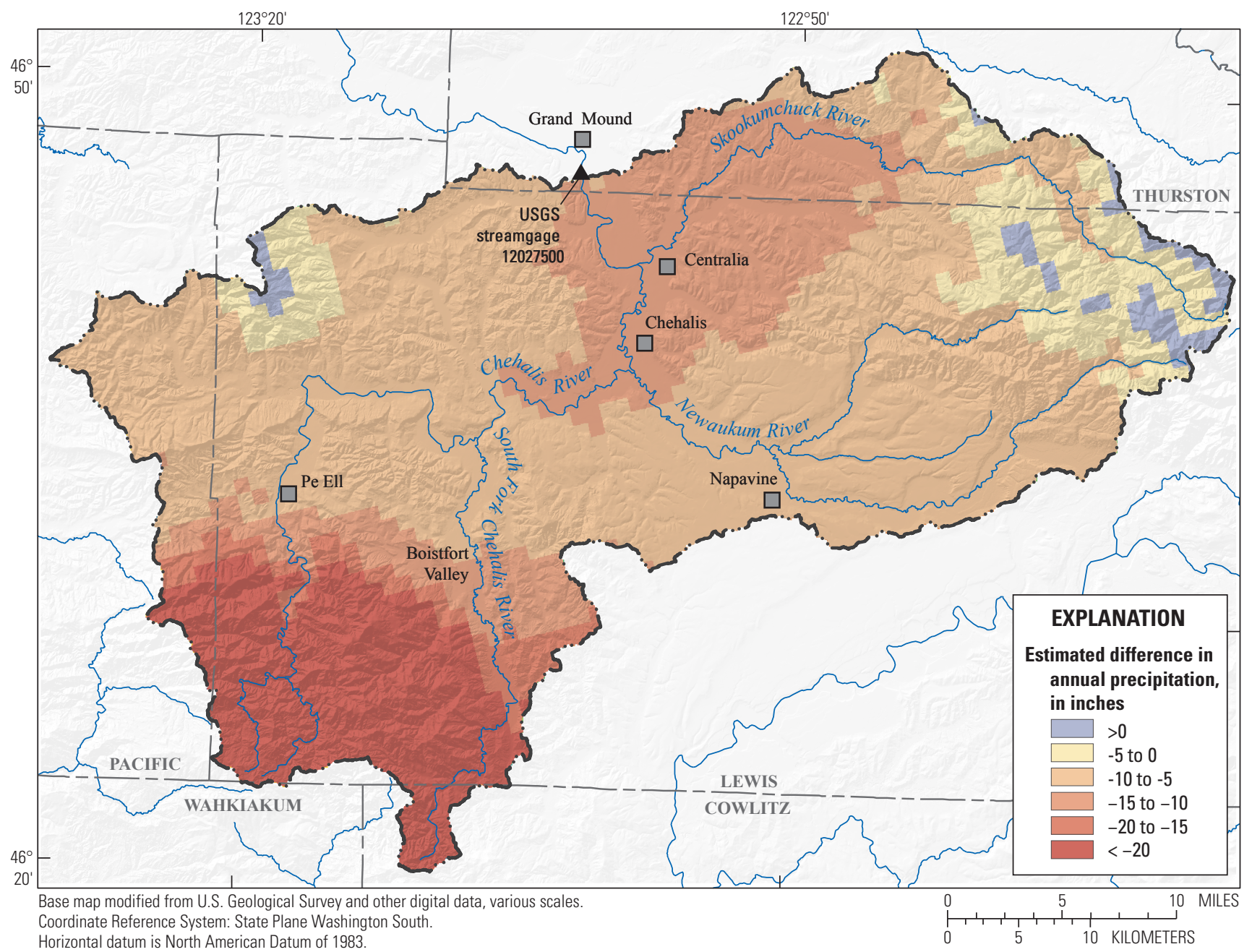

Figure 11. Difference in precipitation in the upper Chehalis River Basin, southwestern Washington, between water year 2015 and the average of water years 2001-15. 


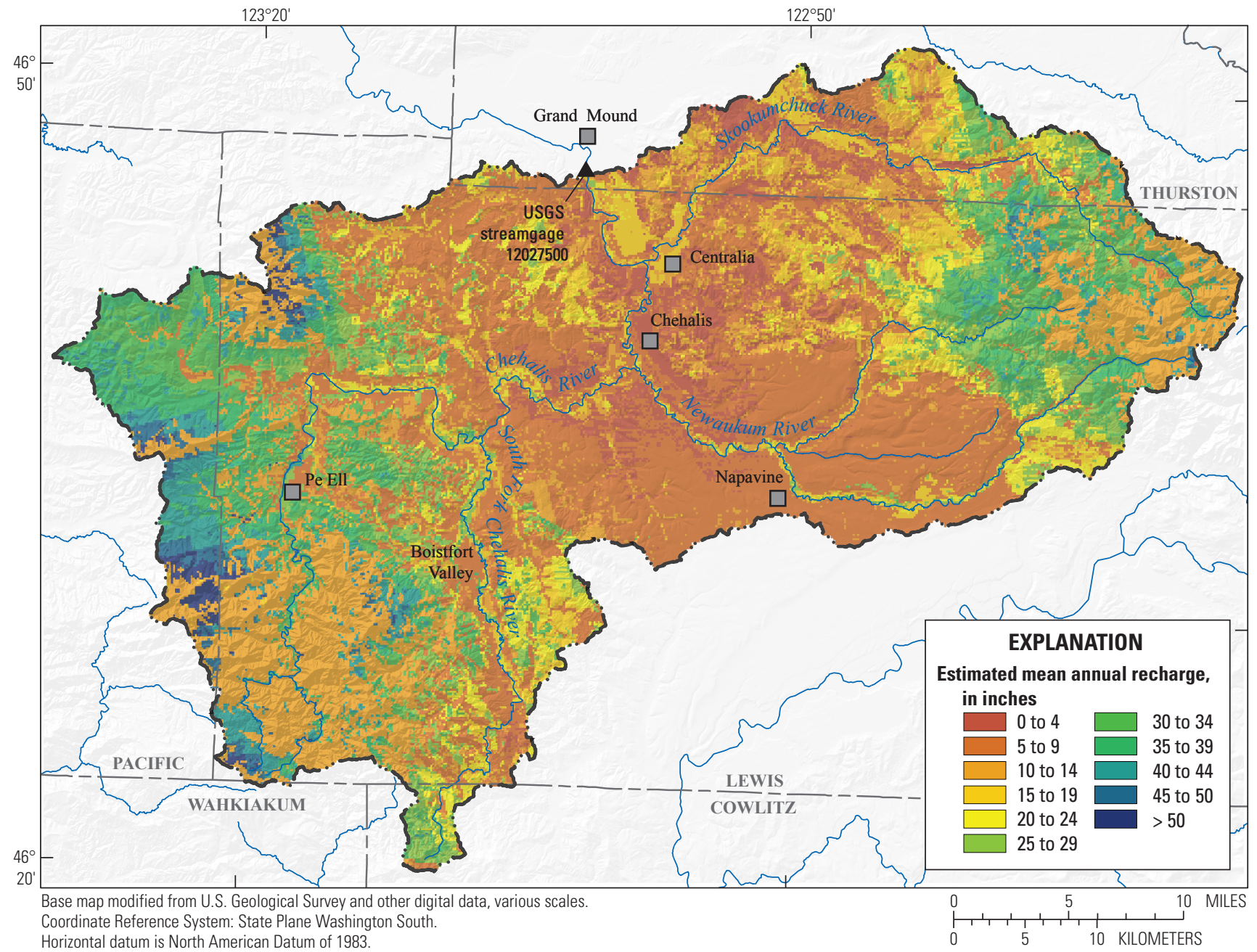

Figure 12. Mean annual recharge estimated by the Soil-Water-Balance model for the upper Chehalis River Basin, southwestern Washington, water year 2015. 


\section{Summary}

Water budget components of the upper Chehalis River Basin in southwestern Washington averaged for water years 2001-15 were estimated by Soil-Water-Balance (SWB); base-flow separation of the hydrograph recorded by the streamgage at the outlet of the basin; and groundwater pumpage from public water purveyor records, census population data, and water-use estimates. In the absence of groundwater or surface-water inputs to the basin, mean annual precipitation (estimated at 72.6 inches) was the single input of water into the basin. Nearly equal parts of water that fell as precipitation left the basin as evapotranspiration (35 percent), surface runoff (30 percent), or recharged groundwater (30 percent). An additional 5 percent did not reach the ground because of interception. The spatial distribution of groundwater recharge was controlled by soil properties and precipitation patterns, with the highest rates of recharge occurring in areas of high precipitation with relatively permeable soil types. Groundwater recharge estimated by SWB was within 17 percent of base flow estimated by hydrograph separation. Groundwater pumpage by Group A and B public-supply systems, self-supply domestic wells, and irrigation wells was estimated at 0.21 inches or about 1 percent of estimated recharge. Estimated water-budget components may be used to inform the future development of numerical groundwater-flow models to support decisions by managers of water resources in the upper Chehalis River Basin.

\section{References Cited}

Burns, D.A., 2002, Stormflow-hydrograph separation based on isotopes-The thrill is gone-What's next?: Hydrological Processes, v. 16, no. 7, p. 1515-1517. [Also available at https://doi.org/10.1002/hyp.5008.]

Canadell, J., Jackson, R.B., Ehleringer, J.R., Mooney, H.A., Sala, O.E., and Schulze, E.D., 1996, Maximum rooting depth of vegetation types at the global scale: Oecologia, v. 108, no. 4, p. 583-595, https://doi.org/10.1007/ BF00329030.

Cronshey, R., McCuen, R., Miller, N., Rawls, W., Robbins, S., and Woodward, D., 1986, Urban hydrology for small watersheds - TR-55 (2d ed.): U.S. Department of Agriculture, Soil Conservation Service, Engineering Division, Technical Release 55, 164 p.
Dripps, W.R., and Bradbury, K.R., 2007, A simple daily soilwater balance model for estimating the spatial and temporal distribution of groundwater recharge in temperate humid areas: Hydrogeology Journal, v. 15, no. 3, p. 433-444. [Also available at https://doi.org/10.1007/s10040-007-0160-6.]

Drost, B.W., Ely, D.M., and Lum, W.E., II, 1999, Conceptual model and numerical simulation of the ground-water-flow system in the unconsolidated sediments of Thurston County, Washington: U.S. Geological Survey Water-Resources Investigations Report 99-4165, 254 p.

Ely, D.M., Frasl, K.E., Marshall, C.A., and Reed, F., 2008, Seepage investigation for selected river reaches in the Chehalis River Basin, Washington: U.S. Geological Survey Scientific Investigations Report 2008-5180, 12 p.

Gendaszek, A.S., 2011, Hydrogeologic framework and groundwater/surface-water interactions of the Chehalis River Basin, Washington: U.S. Geological Survey Scientific Investigations Report 2011-5160, 42 p.

Hargreaves, G.H., and Samani, Z.A., 1985, Reference crop evapotranspiration from temperature: Applied Engineering in Agriculture, v. 1, no. 2, p. 96-99, https://doi. org/10.13031/2013.26773.

Healy, R.W., 2010, Estimating groundwater recharge: Cambridge, United Kingdom, Cambridge University Press, 245 p., https://doi.org/10.1017/CBO9780511780745.

Homer, C., Dewitz, J., Fry, J., Coan, M., Hossain, N., Larson, C., Herold, N., McKerrow, A., VanDriel, J.N., and Wickham, J., 2007, Completion of the 2001 National Land Cover Database for the conterminous United States: Photogrammetric Engineering and Remote Sensing, v. 73, no. 4, p. 337-341.

Lane, R.C., 2009, Estimated water use in Washington, 2005: U.S. Geological Survey Scientific Investigations Report 2009-5128, 30 p.

Lane, R.C., and Welch, W.B., 2015, Estimated freshwater withdrawals in Washington, 2010: U.S. Geological Survey Scientific Investigations Report 2015-5037, 48 p., https:/ doi.org/10.3133/sir20155037.

Natural Resources Conservation Service, 2004, Hydrologic soil-cover complexes, chap. 9 of National Engineering Handbook (Part 630-Hydrology): Natural Resources Conservation Service, 210-VI-NEH, 20 p. [Also available at http:/www.wcc.nrcs.usda.gov/ftpref/wntsc/H\&H/ NEHhydrology/ch9.pdf.] 
Natural Resources Conservation Service, 2014, Web soil survey-Natural Resources Conservation Service Soil Survey Geographic (SSURGO) database: Natural Resources Conservation Service database, accessed March 12, 2018, at https://websoilsurvey.nrcs.usda.gov/.

Risser, D.W., Gburek, W.J., and Folmar, G.J., 2005, Comparison of methods for estimating ground-water recharge and base flow at a small watershed underlain by fractured bedrock in the Eastern United States: U.S. Geological Survey Scientific Investigations Report 2005-5038, $31 \mathrm{p}$.

Sloto, R.A., and Crouse, M.Y., 1996, HYSEP—A computer program for streamflow hydrograph separation and analysis: U.S. Geological Survey Water-Resources Investigations Report 96-4040, 46 p.

Smith, E.A., and Westenbroek, S.M., 2015, Potential groundwater recharge for the State of Minnesota using the Soil-Water-Balance model, 1996-2010: U.S. Geological Survey Scientific Investigations Report 2015-5038, 85 p., https://doi.org/10.3133/sir20155038.

Stewart, M., Cimino, J., and Ross, M., 2007, Calibration of base flow separation methods with streamflow conductivity: Ground Water, v. 45, no. 1, p. 17-27, doi:10.1111/j.17456584.2006.00263.x.

Thornthwaite, C.W., and Mather, J.R., 1955, The water balance, in Publications in climatology, volume 8, number 1: Centeron, New Jersey, Laboratory of Climatology, p. 1-104.

Thornthwaite, C.W., and Mather, J.R., 1957, Instructions and tables for computing potential evapotranspiration and the water balance, in Publications in climatology: Centerton, New Jersey, Drexel Institute of Technology, Laboratory of Climatology, v. X, no. 3, p. 185-311.

Thornton, P.E., Thornton, M.M., Mayer, B.W., Wei, Y., Devarakonda, R., Vose, R.S., and Cook, R.B., 2017, Daymet-Daily surface weather data on a $1-\mathrm{km}$ grid for North America, version 3: Oak Ridge, Tennessee, ORNL DAAC Distributed Active Archive Center for Biochemical Dynamics web page, https://doi.org/10.3334/ ORNLDAAC/1328.
Tillman, F.D., 2015, Documentation of input datasets for the soil-water balance groundwater recharge model of the upper Colorado River Basin: U.S. Geological Survey Open-File Report 2015-1160, 17 p., https://doi.org/10.3133/ ofr20151160.

U.S. Geological Survey, 2016, Soil-Water-Balance (SWB) for estimating groundwater recharge: U.S. Geological Survey web page, accessed March 21, 2018, at https://www.usgs. gov/software/swb-modified-thornthwaite-mather-soil-waterbalance-code-estimating-groundwater-recharge.

Vaccaro, J.J., Hansen, A.J., and Jones, M.A., 1998, Hydrogeologic framework of the Puget Sound aquifer system, Washington and British Columbia: U.S. Geological Survey Professional Paper 1424-D, 77 p.

Washington State Department of Agriculture, 2018, Agricultural land use: Washington State Department of Agriculture geodatabase, accessed March 1, 2017, at https:// agr.wa.gov/pestfert/natresources/aglanduse.aspx.

Washington State Department of Health, 2018, Sentry internet home page: Washington State Department of Health Division of Environmental Health database, accessed March 2018, at https://fortress.wa.gov/doh/eh/portal/odw/si/Intro. aspx.

Washington State Office of Financial Management, 2018, Census geographic files - Census 2010 data: Office of Financial Management database, accessed May 2, 2018, at http://www.ofm.wa.gov/pop/geographic/tiger.asp.

Westenbroek, S.M., Kelson, V.A., Dripps, W.R., Hunt, R.J., and Bradbury, K.R., 2010, SWB-A modified Thornthwaite-Mather soil-water-balance code for estimating groundwater recharge: U.S. Geological Survey Techniques and Methods, book 6, chap. A31, 60 p. [Also available at http://pubs.usgs.gov/tm/tm6-a31/.] 

Publishing support provided by the U.S. Geological Survey

Science Publishing Network, Tacoma Publishing Service Center

For more information concerning the research in this report, contact the Director, Washington Water Science Center

U.S. Geological Survey

934 Broadway, Suite 300

Tacoma, Washington 98402

https://wa.water.usgs.gov/ 
